tories Ltd.), Dr. H. J. Stern (H. J. Stern's Laboratory Ltd.) and Dr. A. N. Worden (Huntingdon Research Centre). Dr. M. Barent (Barent and Johnson), the retiring chairman, was appointed liaison officer with the Union Internationale des Laboratoires Independant, to which the Association is affiliated as the United Kingdom and Commonwealth representative association.

\section{Keilin Memorial Fund}

THE following statement has been received by the Editor of Nature: "With a number of our colleagues we have been considering how best to commemorate the scientific achievements of David Keilin. We believe that the establishment of a Keilin Memorial Lecture under the auspices of the Biochemical Society would perpetuate his memory and be of enduring value. It is hoped to hold the lecture every two years, and to realize this aim it will be necessary to establish a fund of $£ 3,000$ (8,400 dollars). The Biochemical Society has agreed to administer the fund". The statement is signed by Dr. B. Chance, Dr. M. Dixon, Dr. E. F. Hartree, Dr. R. Hill, Dr. T. Mann, Dr. M. F. Perutz, Dr. E. C. Slater, Dr. Emil L. Smith and Dr. P. Tate. Anyone wishing to contribute to the fund can obtain further information from Dr. E. F. Hartree, Animal Research Station, 307 Huntingdon Road, Cambridge.

\section{U.K. Courses in Nuclear Energy, 1963-64}

UNDER the heading of "U.K. Courses in Nuclear Energy, 1963-65" the May 1963 list of Nuclear Studies, compiled by the Science Department of the British Council, was noted on p. 1042 of the June 15 issue of Nature. The note refers to List No. 7 and not List No. 6 as stated. The note also mentioned that "The list has unavoidably appeared too late for application to be made for any of the courses for the academic year 1963-64"'. This is incorrect and should read "The list has unavoidably appeared too late for application to be made for many of the courses for the academic year 1963-64". Applications need not be submitted a long time in advance for many of the shorter courses. Furthermore, the List does not, in fact, include any courses for 1965 , except by implication where courses are run annually.

\section{University News:}

Aberdeen

Dr. D. J. F. Bowling has been appointed to a lectureship in botany, and Dr. M. N. Court to a lectureship in soil science.

Durham

THE seventeenth annual report of the University of Durhøm Appointments Board for 1961-62 reports that although significantly larger numbers completed courses in 1962 than in 1961, the demand in several sectors, notably chemical, oil and engineering industry, declined (Pp. 12. Durham: The University, 1963). As yet, the Board sees no signs that scientists or engineers, who would have reasonable prospects of success in, say, the Home Civil Service Administrative or Foreign Service competitions, are being attracted in those directions. Industrial demand for arts graduates also suffered a sctback, but the arts graduate with reasonable personal qualities seeking employment outside teaching did not have an especially difficult time. The steady fall betwoen 1958 and 1961 in the number of men joining nationalized industries and public utilities and corporations was reversed in 1962, and public service has increased its share of Durham graduates over the past five years. Reference is also made to the increasing numbers entering university employment, technical colleges and farm institutes, and the increased proportion of men graduates still seeking employment at the end of 1962 is attributed largely to the slack and uncertain state of the economy.
Liverpool

Prof. W. H. F. Barnes, professor of moral philosophy in the University of Edinburgh, has been appointed vicechancellor in succession to Sir James Mountford, who retires on September 30 .

London

THE title of professor of chemical engineering has been conferred on Mr. S. B. Watkins in respect of his post at King's College. The title of reader in aeronautical engineering has been conferred on Dr. G. J. Hancock in respect of his post at Queen Mary College.

\section{Announcements}

Sir IsAac Wolfson, BART., has been elected a Fellow of the Royal Society, under the Statute of the Royal Society which provides for the election of persons who either have rendered conspicuous service to the cause of science or are such that their election would be of signal benefit to the Society.

DR. K. R. PAyne has been appointed general manager of L. Light and Co., Ltd., with effect from May 16, in succession to Mr. G. R. Jones, who is leaving the Company.

The second International Pharmacological Meeting will be held in Prague during August 20-23. Further information can be obtained from the Secretariat of the Second International Pharmacological Meeting, Albertov 4, Prague 2.

THe thirty-ninth annual Plant Pathology Field Meeting, arranged by the British Mycological Society, will be held at the East Malling Research Station on July 18. Further information can be obtained from Dr. R. C. F. Macer, Plant Breeding Institute, Maris Lane, Trumpington, Cambridge.

The thirteenth general assembly of the International Union of Geodesy and Geophysics is to be held on the campus of the University of California at Berkeley during August 19-31. Further information can be obtained from the Local Arrangements Committee, International Union of Geodesy and Geophysics, University of California, Berkeley, 4, California.

THE fifth International Congress of Clinical Chemistry, organized by the American Association of Clinical Chemists and the Canadian Society for Clinical Chemistry, will be held in Detroit, Michigan, during August 19-23. Further information can be obtained from the secretary, Dr. D. G. Remp, Henry Ford Hospital, Detroit 2, Michigan.

THe fourth Australian Spectroscopy Conference, organized by the Spectroscopy Committee of the Australian Academy of Science, will be held at the Australian National University, Canberra, during August 20-23. Further information can be obtained from Dr. S. R. Taylor, Department of Geophysics, Australian National University, Canberra.

Av international conference on "Lattice Dynamics", organized by the Danish Academy of Technical Sciences, the Danish Physical Society, the International Union of Pure and Applied Physics, NORDITA, the U.S. National Science Foundation and the U.S. Office of Naval Research, will be held at the Technical University of Denmark, Copenhagen, during August 5-9. Further information can be obtained from Dr. S. Lundqvist, Department of Mathematical Physics, Chalmers University of Technology, Göteborg, Sweden.

Erratum. Referring to his communication in Nature of May 18, p. 678, Dr. S. M. Silverman writes that the times which he gave on the individual scales in Fig. 2 are incorrect. They should read, from top to bottom (U.T.): $1155,1055,1025$ and 0955. 